\title{
Potentially new emerging diseases on two species of Indonesian freshwater aquaculture: giant gourami (Osphronemus gourami) and Asian catfish (Pangasius hypophthalmus)
}

\author{
Hessy Novita ${ }^{1, *}$, Septyan Andriyanto ${ }^{1}$, Tuti Surniati ${ }^{1}$, and Taukhid ${ }^{1}$ \\ ${ }^{1}$ Research Station For Fish Disease Control, Research Institute for Freshwater Aquaculture and \\ Fisheries Extension (RIFAFE), Jalan Perikanan Raya No. 13 Pancoran Mas, Depok 16436, Indonesia
}

\begin{abstract}
Disease outbreaks and mortality in giant gourami and Asian catfish (pangasius) culture have been frequently reported during the last decade. Etiological agents of the disease have remained unknown, so it is needed to explore epidemiological studies to know the main causative agents. The study aimed to know the main pathogenic agents who were identified during disease outbreaks on giant gourami and pangasius. Data and information were collected through active and passive surveillance at the production centers of each species. Analysis was carried out according to standard fish disease diagnosis and eventually was focused on two suspected new emerging diseases (NED), namely Infectious Spleen and Kidney Necrosis Virus (ISKNV) belonging to Megalocytivirus on giant gourami and Enteric Septicemia of Catfish (ESC) caused by Edwardsiella ictaluri on pangasius. The results showed that ISKNV was detected on most of the diseased giant gourami samples and that E. ictaluri was identified on most diseased pangasius samples. This study concluded that both pathogenic agents, Megalocytivirus and E. ictaluri were suspected to be potentially NED on freshwater aquaculture, especially infecting giant gourami and pangasius respectively.
\end{abstract}

\section{Introduction}

Gouramy (Osphronemus gouramy) and catfish (Pangasius hypophthalmus) are freshwater aquaculture commodities contributing to food security, welfare improvement programs, and foreign exchange earnings. The development and increase in the production of these two types of fish can be done by intensifying sustainable aquaculture. The intensive cultivation must be supported by fulfilling key requirements such as the availability of quality seeds, intact and environmentally friendly cultivation technology, good quality feed, and health management.

Regarding fish health management, disease outbreaks in the cultivation of gouramy and catfish have been reported in several production centers of those commodities. The mass death of gouramy in the second semester of 2017-first semester of 2018 in Central

\footnotetext{
* Corresponding author: hestahamdani@gmail.com
} 
Java (Purbalingga, Banjarnegara, and Banyumas) and West Java (Banjar, Ciamis, and Tasikmalaya) resulted in economic losses of IDR 30 billion[1], especially tens of thousands of productive gourami brooders. These two regions are the largest suppliers of gouramy eggs and fry in Indonesia [2], and until now, death cases are still occurring with varying percentages [3]. In the same period, disease outbreaks also occurred in catfish farming in East Java (Tulung Agung) and South Sumatra [4]. Epidemiological studies related to disease outbreaks in these two commodities have not been carried out comprehensively. Therefore, the main causes and determinant factors that trigger the outbreak are still not yet known.

In 2019, a similar case was experienced again by gourami fish farmers in West Java, Central Java, Yogyakarta, and East Java. As an illustration, in the April-July 2019 period, tens of thousands of brooders and prospective brooders of gouramy died in the Yogyakarta region. Yogyakarta [5] and significant reductions in survival were also experienced by catfish cultivators in Tulung Agung and South Sumatra [6].

The type of infectious disease considered the main disease in gourami is a bacterial disease caused by infection of Mycobacterium sp. and Aeromonas sp., or co-infection by both bacterial genera [7.8]. Cases of disease in gourami caused by the involvement of a viral infection, Megalocytivirus, which causes infectious spleen and kidney necrosis virus (ISKNV), have been reported by [9] in West Java, Central Java, and Bali. In catfish culture, the main diseases are parasitic protozoan infection in fry and motile aeromonads septicemia (MAS) disease in rearing. In the end, it was also known that there was the involvement of Edwardsiella ictaluri bacterial infection, both in hatcheries and grow-out stage [7.8].

The development of the intensive cultivation of carp and catfish requires a serious concern on the health management system. The emergence of a new disease has the potency to become a technical obstacle. Therefore it needs to be anticipated to reduce the negative impact of the disease. Systems and strategies for controlling diseases caused by infectious, endemic, and lethal pathogens in aquaculture must be based on epidemiological studies. This study aims to determine the main pathogens involved in disease cases that are potentially new emerging diseases in the cultivation of gouramy and catfish. Based on the facts of disease cases in the field combined with the technical information that has been revealed, this study focuses on two types of viral disease (ISKNV) in gouramy, Enteric Septicemia of Catfish (ESC) disease in catfish.

\section{Material and methods}

\subsection{Sampling}

The collection of data and information was done through 2 methods, (1). active surveillance in the production center of gouramiy and catfish, and (2). passive surveillance, samples sent to the Laboratory - Research Center for Freshwater Aquaculture and Fisheries Extension (RIFAFE). The samples were taken by carp and catfish cultivation development centers in DKI Jakarta, West Java, Central Java, DI Yogyakarta, and East Java. Technical information relevant to the test sample and disease outbreaks were collected through interviews with stakeholders, equipped with a structured questionnaire to obtain epidemiological status and parameters. The data were analyzed to obtain trends in the main indicators as a material for technical considerations (pathogenicity, mortality rate, susceptibility measures, and trigger factors) in the further verification process that needs to be carried out experimentally. 


\subsection{Parasite identification}

Parasite examination, preparation, and observation procedures were carried out according to the standard work instructions for the parasite examination method. The sample was placed on a glass object, observed meristic-morphometrically using a microscope, and identified according to $[10,11,12,13]$. Analysis was carried out on the prevalence of infection and the abundance of parasites calculated according to the formula [14]:

$$
\text { Prevalence }=\frac{\text { Total number of fish infected with parasites }}{\text { Number of fish samples observed }} \times 100 \%
$$

\subsection{Bacterial isolation}

Bacterial examination, preparation, and isolation procedures were carried out according to the standard for the Bacteria examination method. If no injuries or specific clinical symptoms were found in the test sample, then bacterial isolation was taken from the target organs such as the liver, spleen, brain, muscle, intestine, and kidney. Bacterial characterization was carried out conventionally through biochemical tests [15].

\subsection{Virus detection}

Virus examination and test samples are taken selectively and/or randomly based on health conditions and visually observed clinical symptoms. Aseptically and individually and/or pooling, organs such as gills, kidneys, spleen, liver, eyes, and brain were taken and immediately put into a preservative solution in the form of RNA later or a mixed solution containing absolute ethanol + glycerol $(80: 20, \mathrm{v} / \mathrm{v})$. The molecular ISKNV test was carried out according to the method developed [16] using primers designed from the nucleotide sequence 959-bp Pst I restriction fragment-DDBJ accession number AB006954 of RSIV genome DNA: 1F: 5'CTCAAACACTCTggCTCATC'3 and 1R: 5' GCACCAACACATCTCCTATC'3; sequences of the red iridovirus (RSIV) DNA genome with a target molecular weight of $570 \mathrm{bp}$. The information on the test results was analyzed qualitatively and quantitatively, then presented in the form of a structured tabulation. Conclusions are drawn based on a balanced combination of data/information obtained with available reference studies.

Sequencing of the DNA from the PCR results above was carried out at the 1st BASE in Singapore. The sequence data was then edited using Clustal $\mathrm{W}$ in the MEGA X program with Construct/Test Neighbor-joining tree and Bootstrap method 1000 Replications. and the results were compared with the existing sequences on GeneBank by using the Basic Local Alignment Search Tool (BLAST) search on the NCBI website (http://www.ncbi.nlm. nih.gov).

\section{Results}

The analysis results of test samples obtained from the outbreak areas during the 2018-2019 period found the involvement of bacterial infections, both of which have been considered as the main diseases in goramy, such as mycobacteriosis (Fish-TB) and motile aeromonads septicemia (MAS), as well as other types of bacteria other. The same test sample found that Megalocytivirus causes infectious spleen and kidney stain virus (ISKNV). The results of identification/characterization and detection of pathogens in gouramy are presented in 
Table 1. The electrophoretic profile of the detection of the Megalocytivirus gene can be seen in Figure 1.

In Table 1, it can be seen that in the gouramy population that was experiencing cases of a disease in the sampling area, ISKNV infection was detected. Megalocytivitus infection was found in gouramy from West Java with a prevalence of $38.46 \%$; East Java (100\%), and Yogyakarta (20\%). Based on available data/information, in general, it can be said that samples were taken at the time of a disease outbreak case always found involvement of ISKNV infection, either as a single pathogenic infection or co-infection with other groups of pathogenic agents such as bacteria. Mycobacterium sp., Aeromonas sp., Pseudomonas sp. and Listeria sp.

Table 1. Pathogenic agents were identified on giant gourami (O. gouramy) with active surveillance and passive surveillance methods.

\begin{tabular}{|c|c|c|c|c|c|c|c|c|}
\hline \multirow{2}{*}{ No. } & \multirow{2}{*}{ location } & \multirow{2}{*}{$\sum_{\text {samples }}$} & \multicolumn{2}{|c|}{ parasite } & \multicolumn{2}{|c|}{ bacteria } & \multicolumn{2}{|c|}{ Virus } \\
\hline & & & species & $\begin{array}{l}\text { Prevalence } \\
(\%)\end{array}$ & species & $\begin{array}{c}\text { Prevalence } \\
(\%)\end{array}$ & species & $\begin{array}{c}\text { Prevalence } \\
(\%)\end{array}$ \\
\hline 1 & West Java & 40 & $\begin{array}{l}\text { Dactylogyrus sp. } \\
\text { Gyrodactylus sp. } \\
\text { Ich. multifiliis } \\
\text { Trichodina sp. } \\
\text { Haneguya sp. } \\
\text { Paramecium sp. } \\
\text { Epistilis sp. }\end{array}$ & \begin{tabular}{|l}
15.0 \\
2.5 \\
10.0 \\
30.0 \\
2.5 \\
2.5 \\
2.5
\end{tabular} & $\begin{array}{l}\text { Aeromonas sp. } \\
\text { Kurthia } s p . \\
\text { Listeria sp. } \\
\text { Mycobacterium sp. } \\
\text { Pseudomonas sp. } \\
\text { Staphylococcus sp. }\end{array}$ & \begin{tabular}{|l|}
8.0 \\
2.5 \\
27.5 \\
12.0 \\
8.0 \\
2.5 \\
\end{tabular} & ISKNV & 38.46 \\
\hline 2 & Jakarta & 5 & - & - & $\begin{array}{l}\text { Listeria sp. } \\
\text { Micrococcus sp. } \\
\text { Pseudomonas sp. } \\
\text { Staphylococcus sp. }\end{array}$ & $\begin{array}{l}20.0 \\
20.0 \\
20.0 \\
20.0\end{array}$ & ISKNV & 20.00 \\
\hline 3 & Central Java & 9 & - & - & - & - & ISKNV & 20.00 \\
\hline 4 & Yogyakarta & 9 & - & - & - & - & ISKNV & 20.00 \\
\hline 5 & East Java & 9 & - & - & $\begin{array}{l}\text { Mycobacterium sp. } \\
\text { Pseudomonas sp. }\end{array}$ & $\begin{array}{l}10.0 \\
10.0\end{array}$ & ISKNV & 100.00 \\
\hline
\end{tabular}

Types of bacteria, Mycobacterium spp., Aeromonas spp., Pseudomonas spp., and Staphylococcus spp. from West Java, East Java, and Central Java, are commonly found in carp culture, and it epizootiological characteristics have been well described. Meanwhile, Listeria spp is more commonly found as a foodborne pathogen in fish and fish products. Its epizootiological characteristics need to be studied further and Kurthia spp., which is also rarely found in carp.

Generally, parasites infections were found in gourami seeds with a very low prevalence of infestation (2.5\%). Those parasites, namely Gyrodactylus sp., Haneguya sp., Aramecium $s p$., and Epistilis sp., while the parasite Ichthyophthirius multifiliis, Dactylogirus $s p$. and Trichodina sp. have a prevalence of $10 \%, 15 \%$, and $30 \%$, respectively. The parasites were found from the sampling area of 40 samples of gouramy from West Java. In contrast, no parasites were found in gouramy samples from Jakarta, Central Java, East Java, and Yogyakarta. Gouramy samples were taken from the location of the disease outbreak as well as secondary information from stakeholders, most of which were affected by the disease outbreak was the size of consumption, prospective broodstock, and productive broodstock; 
so that the suspicion of infection with parasitic pathogens as the main pathogen can be ignored.

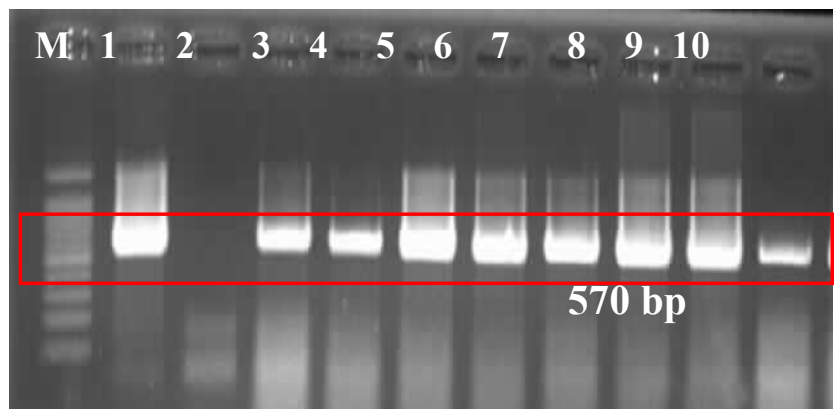

Fig. 1. Electrophoresis profile of Megalocytivirus with the amplicon target at $570 \mathrm{bp}$ on giant gouramy $(O$. gourami $) . \mathrm{M}=100 \mathrm{bp}$ DNA marker, $1=$ positive control, $2=$ negative control, 3, 4 (West Java), 5, 6 (Yogyakarta); 7, 8 (East Java); 9, 10 (Central Java ).

The viral DNA sequencing analysis results using BLASTn were identified as ISKNV in samples from Jogjakarta, East Java, Central Java, and West Java with 92-98\% homology. The distribution of ISKNV found in gouramy can be seen in Table 2.

Table 2. Result of ISKNV with active surveillance and passive surveillance methods.

\begin{tabular}{|c|l|l|c|c|}
\hline $\begin{array}{c}\text { Sample } \\
\text { code }\end{array}$ & \multicolumn{1}{|c|}{ Origin } & \multicolumn{1}{|c|}{ homolog } & $\begin{array}{c}\text { Identities } \\
(\%)\end{array}$ & Accession \\
\hline JBR & West Java & $\begin{array}{l}\text { Infectious spleen and kidney } \\
\text { necrosis virus isolate } \\
\text { NBFGR:ISKNV:C5 laminin-like } \\
\text { protein gene, partial cds }\end{array}$ & 99 & $\underline{\text { MT224134.1 }}$ \\
\hline JTE & Central Java & $\begin{array}{l}\text { ISKNV isolate case7 ORF022L } \\
\text { and ORF023R genes, partial cds }\end{array}$ & 98 & $\underline{\text { KX354215.1 }}$ \\
\hline JTM & East Java & $\begin{array}{l}\text { ISKNV isolate } \\
\text { BFGR:ISKNV:C5 laminin-like } \\
\text { protein gene, partial cds }\end{array}$ & 98 & $\underline{\text { MT224134.1 }}$ \\
\hline JGK & Jogjakarta & $\begin{array}{l}\text { ISKNV isolate case7 ORF022L } \\
\text { and ORF023R genes, partial cds }\end{array}$ & 92 & $\underline{\text { KX354215.1 }}$ \\
\hline
\end{tabular}

The phylogeny results using MEGA $\mathrm{X}$ on virus samples from each region indicate that this virus belongs to the ISKNV group, which can be seen in Fig. 2.

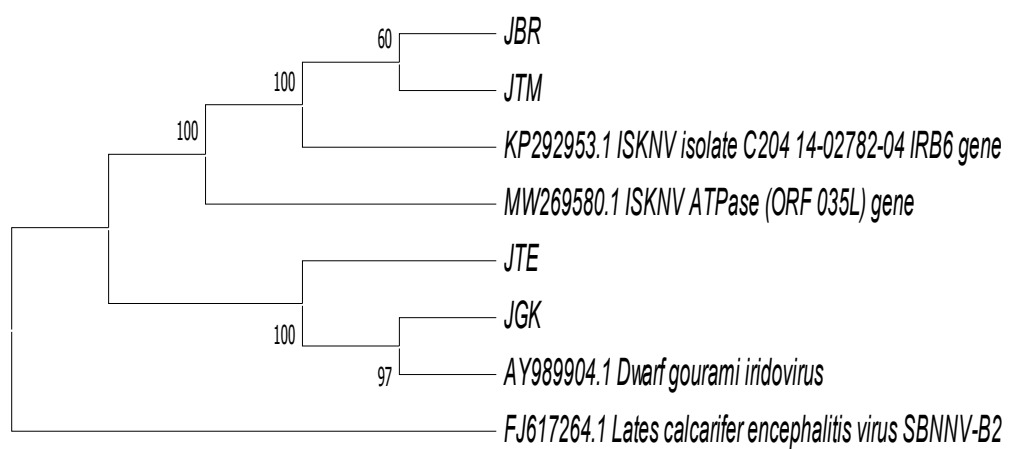


Fig. 2. The ISKNV phylogenetic tree constructed using the Neighbor-Joining method in MEGA X with L. calcarifer encephalitis virus (SBNNV-B2) was used as the outgroup. Bootstrap value in 1000 replications.

The results of the analysis of catfish samples obtained during cases of illness and death, always found the involvement of $E$. ictaluri bacteria infection, both in the format as a single infectious pathogenic agent or co-infection with $A$. hydrophila bacteria from West Java, Central Java, and East Java. Clinical symptoms are considered as disease-specific ESC according to [17] is the presence of white patches, which are hemorrhages (necrotic foci) on internal organs. The results of identifying pathogens in catfish are presented in Table 3, and the description of specific clinical symptoms can be seen in Fig. 3.

Table 3. Pathogenic agents were identified on pangasius ( $P$. hypophthalmus) with active surveillance and passive surveillance methods

\begin{tabular}{|c|c|c|c|c|c|c|}
\hline \multirow[b]{2}{*}{ No. } & \multirow[b]{2}{*}{ location } & \multirow[b]{2}{*}{$\sum_{\text {Samples }}$} & \multicolumn{2}{|c|}{ parasite } & \multicolumn{2}{|c|}{ Bacteria } \\
\hline & & & species & $\begin{array}{l}\text { Preva } \\
\text { lence (\%) }\end{array}$ & species & $\begin{array}{c}\text { Preva } \\
\text { lence } \\
(\%)\end{array}$ \\
\hline 1 & West Java & 74 & $\begin{array}{l}\text { Ich.multifiliis } \\
\text { Oodinium sp. } \\
\text { Trichodina sp. } \\
\text { Dactylogyrus sp. } \\
\text { Gyrodactylus sp. } \\
\text { Vorticella sp. } \\
\text { Argulus sp. } \\
\text { Glostasella sp. }\end{array}$ & $\begin{array}{l}53,33 \\
3,33 \\
50,00 \\
20,00 \\
10,00 \\
3,33 \\
3,33 \\
3,33\end{array}$ & $\begin{array}{l}\text { A.hydrophila } \\
\text { E. ictaluri }\end{array}$ & $\begin{array}{l}77,78 \\
67,87\end{array}$ \\
\hline 2 & East Java & 6 & - & - & E. ictaluri & 50,00 \\
\hline
\end{tabular}

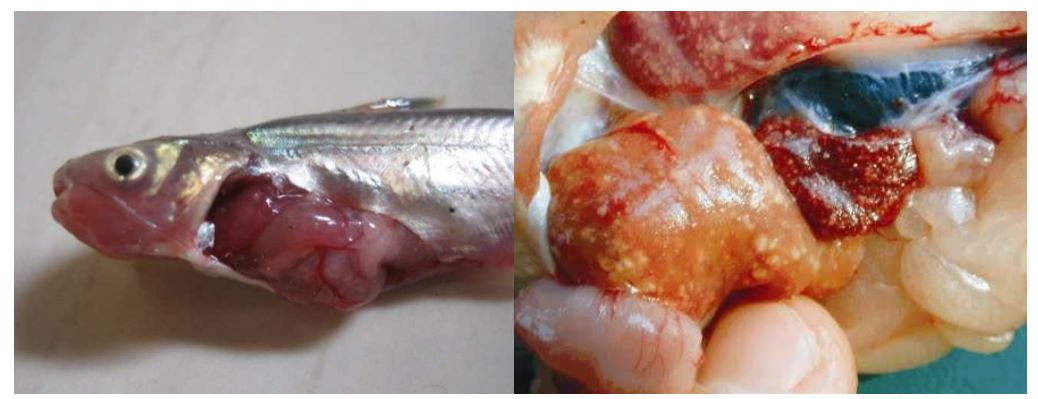

Fig. 3. Specific clinical signs of enteric septicemia of catfish (ESC) caused by E. ictaluri infection on pangasius (P. hypophthalmus)

And the results of the analysis of most of the test samples taken at the time of the occurrence of disease cases, clinical symptoms, and observed patterns of death; It is strongly suspected that the primary aetiological agent causing disease and death in catfish that has recently occurred is ESC disease caused by infection with the bacterium E. ictaluri, either as a single pathogenic infection or co-infection with $A$. hydrophila bacteria. The types of parasites found in catfish with varied prevalence rates, such as in the West Java region, were isolated Ichthophthirius multifiliis Oodinium spp. Trichodina sp. Dactylogyrus sp. Gyrodactylus sp. Vorticella sp. Argulus sp. Glostasella sp., with prevalence about $53.33 \%, 3.33 \%, 50.00 \%, 20.00 \%, 10.00 \%, 3.33 \%$, and $3.33 \%$, respectively. 


\section{Discussion}

Based on data/technical information that is elaborated from observations on samples of sick and/or dying gourami (moribund), generally show clinical symptoms such as weakness, darker color, endophthalmitis/cataract, loose scales and/or peeling skin, erosion, and ulcers; kidney congestion, swelling of the liver and spleen, inflammation of the brain (encephalitis), and ascites (dropsy). These clinical symptoms are used as a presumptive diagnosis in the process of making a definitive diagnosis. Extraction of the overall clinical symptoms found, in general, is more directed to the possibility of an ISKNV infection, according to the description [9].

Grouper viral diseases in finned fish caused by Megalocytivirus infection into three genotypes, namely Infectious Spleen and Kidney Necrosis Virus (ISKNV) [18], Red Seabream Iridovirus (RSIV), and Turbot Red Body Iridovirus (TRBIV), then the virus can cause significant illness and death in both freshwater and marine fish[19]. Fish diseases caused by Megalocytivirus infection are epizootic with a wide host range and spread in various countries [20]. This viral infection has been widely reported in marine fish aquaculture such as grouper and snapper [21, 22]. In contrast, in freshwater fish, it initially often found to infect ornamental gourami, dwarf gourami (Colisa lalia), angelfish (Pterophyllum sp.), ornamental fish cichlids [23,24. 25] and Banggai Cardinal [26]. Megalocytivirus infection in gourami disease cases in West Java, Central Java, and Bali has been reported [9].

The analysis results of most of the test samples taken at the time of the occurrence of disease cases, clinical symptoms, and observed patterns of death; It is strongly suspected that the primary aetiological agent causing disease and death in carp that has occurred recently is Megalocytivirus. The virus acts as a single infectious agent (single pathogenic infection) or co-infection with other groups of pathogenic agents such as Mycobacterium spp. and Aeromonas spp.

Cases of disease and death in catfish reported generally occur in the enlargement business with a size above 300 grams/head. In general, clinical symptoms observed in sick catfish and/or moribunds include weakness, loss of appetite, pale gill color, red spots (petechiae) under the chin, belly, or base of the fins, swimming on the surface or the edge of the pond. With head up, dying fish swim in convulsions and/or whirling, and white patches on internal organs (liver, spleen, and kidneys). These clinical signs generally indicate symptoms of Enteric Septicemia of Catfish (ESC) disease due to E.ictaluri bacterial infection $[17,27,28,29]$

\section{Conclusion}

Infectious ISKNV disease caused by Megalocytivirus infection has the potential to be a newly emerging disease in gourami, either single infection (single pathogenic infection) or co-infection with other pathogenic agents, especially bacteria Mycobacterium sp. and Aeromonas sp. Enteric Septicemia of Catfish (ESC) disease caused by infection with the bacteria $E$. ictaluri has the potential as a newly emerging disease in catfish, both in single infection and co-infection with other pathogenic agents, especially Aeromonas $s p$.

\section{Acknowledgments}

This research was funded by DIPA 2019 Research Institute for Freshwater Aquaculture and Fisheries Extension (RIFAFE), Bogor. The author would like to thank Ahmad Wahyudi, 
Setiadi, Edy Farid, and Johan Afandi for their assistance during the implementation of research activities.

\section{References}

1. Office of fisheries and animal husbandry services of Banyumas Regency, Report of disease cases in gouramy cultivation in Banyumas (Unpublished Report, 2018)

2. Directorate General of Aquaculture (DGA), Report on fish disease and pest monitoring results (Fish Disease Monitoring System Software/SSMPI) (Unpublished Report, 2018)

3. Instalation of integrated aquaculture service of Banyumas Regency, Case report of disease in gouramy culture in Banyumas (Unpublished Report, 2019)

4. Directorate General of Aquaculture (DGA), Report on fish disease and pest monitoring results (Fish Disease Monitoring System Software/SSMPI) (Unpublished Report, 2018)

5. Office of fisheries services of Yogyakarta, Case report of disease and mass death of gouramy in Yogyakarta Region (Unpublished Report, 2019)

6. Directorate General of Aquaculture (DGA), Report development of fish disease monitoring system software/SSMPI (Unpublished Report, 2019)

7. Taukhid, Diseases in freshwater fish farming and their control. Training materials for technical officers for fish disease control and aquaculture environmental management (Unpublished Report, 2017)

8. Directorate General of Aquaculture (DGA), Concerning list of major fish diseases and targets for monitoring fish diseases in 2018 (2018)

9. I. Koesharyani, L. Gardenia, Indonesian Aquaculture J. 8, 1(2013)

10. Z. Kabata, Parasites and diseases of fish cultured in the tropics (Taylor and Francis Ltd., London, 1985)

11. J. Lom, I. Dyková, Protozoan parasites of fishes (Elsevier Science Publisher B.V., Amsterdam, 1992)

12. S. Chinabut, L.H.S Lim. Raffles Bull. Zool. 41, 1 (1993)

13. H.H. Williams, A. Jones, Parasitic worms of fish (Taylor and Francis Ltd., London, 1994)

14. L. Margolis, G.W. Esch, J.C. Holmes, A.M. Kuris, G.A. Schad, J. of Parasitology 68, 1 (1982)

15. B. Austin, D.A. Austin, Bacterial fish pathogens. In disease in farmed and wild fish (Ellis Horwood Ltd., Chichester, 1993)

16. J. Kurita, K. Nakajima, I. Hirono, T. Aoki, Fish Pathol. 33, 1 (1998).

17. Taukhid, S.M. Hastuti, A.M. Lusiastuti, A. Rahman, D.Sugiani, A.S. Sukowati, DJPB. 234 (2018)

18. X. Fu, N. Li, L. Liu, Q. Lin, F.Wang, Y. Lai, H. Jiang, H. Pan, C. Shi, S. Wu, Journal of Virus Genes 42, 97-109 (2010)

19. A.E. Rimmer, J.A. Becker, A. Tweedie, R.J. Whittington, Aquac. 358-359, 155163. (2012)

20. M. Fauquet, A.Mayo, J. Maniloff, U. Desselberger, L.A. Ball, Eighth report of the international committee on taxonomy of viruses Elsevier (Academic Press, San Diego, 2005) 
21. I. Koesharyani, D. Roza, K. Mahardika, F. Jhon, Zafran, K.Yuasa, Diseases of marine fish and crustaceans in Indonesia (in Bahasa Indonesia) (Gondol, Bali, 2001)

22. K. Mahardika, I. Koesharyani, A. Prijono, K. Yuasa, J. Penelitian Perikanan Indonesia 9, 1 (2003)

23. I. Koesharyani, A. Santika, Z. Zainun, A. Suhendra, Jaelani, Maskur, H. Novita, Prosiding Forum Inovasi Teknologi Akuakultur, (2009)

24. J. Verena, A. Mikolaj, W. Peter, W. Jan, We. Helmut, S. Dieter, Dis. Aquat. Org. 119, 239-244 (2016)

25. R.P.E. Yanong, T.B. Waltzek, UF/IFAS Extension FA182 (University of Florida, Gainesville, 2013)

26. D. T. Andriany, I. Koesharyani, J. Ris. Akuakultur 12, 3 (2017)

27. J. C. Newton, L. G. Wolfe, J.M. Grizzle, J.A. Plumb, J. Fish Dis. 12, 335-347 (1989)

28. T. J. Baldwin, J. C. Newton, J. Aquat. Anim. Health 5, 189-198 (1993)

29. OIE, Manual of diagnostic tests for aquatic animals. Chapter 2.1.12, https://www.oie.int/ (2003) 